Bullshit and the Metaphor of Speaking One's Mind

Previous: Letter from the Editors by Thom Bryce, Melissa Dalgleish, Nemanja Protic

Next: Legible Liars: Thackeray's Barry Lyndon as Professor of Imposture by Elizabeth Bleicher

\title{
Bullshit and the Metaphor of Speaking One's Mind
}

Keynote Address

Philip Eubanks

Pivot is published through Open Journal Systems (OJS) at York University 
In 2009, my colleague John Schaeffer and I published an article in College Composition and Communication entitled "A Kind Word for Bullshit: The Problem of Academic Writing." I want to begin by mentioning how we came to write the piece. It's an interesting story, I think. We were originally inspired to write the article in 2005 when the philosopher Harry Frankfurt's classic essay "On Bullshit" was re-issued as a standalone book. When the book came out, there was plenty of hoopla. Frankfurt even did a guest shot on The Daily

\section{Bullshit and the Metaphor of Speaking One's Mind}

\section{Keynote Address}

Show. Schaeffer and I

were eager to read the essay-we hadn't been familiar with it before. Of course, neither of us had any idea that we would eventually write anything about it. It seemed rather far afield from our usual interests.

But a funny thing happened. Shortly after I read the essay, I had a dream - an extraordinarily vivid dream in which Friedrich Nietzsche played an important part. Nietzsche burst in on me in my university office, where I was working in the wee hours of the morning. As it happened, he had just read Frankfurt's "On Bullshit" and was very taken by it. In fact, he seemed to be nearly in a manic state of excitement. His hair looked untamed, his moustache more than usually overgrown. He jabbed his hands in the air. He raved about the "clever beasts who invented knowing" and said to me-in English, by the way: "Don't you see? It's all bullshit. It's always been bullshit." This dream was strange enough. But, as it turned out, John Schaeffer-only a few nights beforehad had a very similar dream that featured not Nietzsche but Jacques Derrida. 
Perhaps I should stop there. None of this is true, as much as I wish it were. Nietzsche never appeared to me in a dream. I have no idea what John Schaeffer dreams about, but I hope it's not Derrida. I have broken my vow (to myself) that I would not bullshit you.

To continue more straightforwardly: It was only once Schaeffer and I read Frankfurt's essay that we recognized that it hit upon a key problem in the study of writing that, to us, has never seemed fully resolved: the question of a writer's self-representation. We were familiar, of course, with arguments about the "self." Many challenge the idea of an authentic core that awaits expression, once the writer-and not least the student writer-digs deeply enough inside of him- or herself. Numerous writing specialists-and, of course, not just writing specialists-have pointed out that the self is not a fixed entity, that it does not occupy a hidden waiting room within our minds or hearts or gut, and that it is only reified, not real, when we claim to express ourselves. In short, the self is a fluid construction that is an amalgam of innumerable influences.

What that has to do with bullshit is simply this. Frankfurt argues rather convincingly that bullshit is not mere lying but is, instead, and perhaps fundamentally so, a misrepresentation of self. So the question has to be asked: If the self is a fluid construction, influenced by a thousand things large and small-if there really is no self-how is it possible to misrepresent it?

But let me pause here to confess that my resolve is weak. I have bullshitted you again. The first time I did it, you probably caught on rather quickly. I told you that Nietzsche came raving to me in a dream. That was bullshit-pure and simple.

The second time I bullshitted you was when I claimed, at some length, that Schaeffer and I became interested in 
bullshit because we realized that it was related to scholarly critiques of the self. In that instance, you may or may not have detected the aroma of male bovine fecal matter. But if you didn't, don't feel too badly. Your bullshit detector is probably in good working order.

For one thing, what I said was at least partly true. Our interest in writing about bullshit was piqued when we realized that questions of bullshit and the self were related. The problem is, that realization did not occur in one fell swoop as I made it seem. It developed in fits and starts, over the course of numerous conversations that, frankly, I can no longer remember. And it only came into sharp focus once we had started writing the essay. Surely, our thought process was recursive, non-linear, perhaps disjointed, and partly unconscious.

So while my account may be as true these kinds of accounts tend to be-the implicit claim that I could provide a succinct explanation of our thought process was really false. My account was false also because I claimed to tell you about two people's thought processes, even though I couldn't even tell you my own. And even if something I said was roughly true, that was only an accident. I falsely represented to you that I remembered the truth of the matter. So I uttered quite a few falsehoods in a fairly short time. But none were the kind that would make a bullshitter proud.

I did bullshit you, but it wasn't the kind of bullshit done for the sake of factual deception. Rather it was the kind of bullshit that is meant to misrepresent the self (whatever that may be). It was designed to construct an image of me as a rational scholar. Moreover, it played into a larger notion of academic study as a rational and disinterested enterprise. My change of diction was part and parcel of that, of course. I began this piece with language like "working in the wee hours of the morning," but then turned academic on you with 
phrases like "a fluid construction that is an amalgam of innumerable influences." In sum, I tried to favorably construct my ethos in a way that would help you to favorably construct your own. And to the extent that we are kidding each other, it's really just bullshit.

So, then, why have I begun by bullshitting you not once but twice? I've done it in order to contrast what Schaeffer and I have called prototypical bullshit from a more acceptable variety of non-prototypical bullshit that, we think, characterizes most academic writing. That is the basis of our addendum - or challenge-vis-à-vis Harry Frankfurt. Frankfurt reasons well that bullshit can be a matter not of lying but merely of misrepresentation of the self. At the same time, though, he uses what Coleman and Kay-famous for their analysis of the word to lie-call the "checklist method" of definition. He identifies qualities that bullshit may have and tries to define it by its necessary qualities.

But that is somewhat misguided, I would insist. By emphasizing what might possibly be considered bullshit, Frankfurt ends up defining it by odd rather than ordinary instances. I agree with Coleman and Kay-and many other cognitive linguists - that words name categories and that categories are graded. There are central instances-the prototypical ones-and peripheral instances. This view can be traced back to Eleanor Rosch's experiments in which, for example, robin was listed more often and identified more quickly as a bird than, say, emu. An emu is just as much a bird as a robin is. But it's not the first bird that comes to mind. Likewise, non-lying bullshit is just as much bullshit as lying bullshit. But it's not the central case.

We noted in our essay that we-academic writers, that istake great care to write things that are mostly accurate, but we also craft our writing in a way that constructs a credible public representation of self: an acceptable professional 
ethos. That sort of non-prototypical bullshit is not necessarily a bad thing, we said. If it is false in ways, it also reminds us of what we should aspire to be. It is a version of "fake it till you make it." Virtually all academic writers do it, and within certain ethical limits we ought to tolerate it when our students do the same thing.

I want to raise a different question here, however. A riskier question, I think. What if we were too timid? What if bullshit can lead us to something better than just "our better selves"? At least where our advanced students are concerned, shouldn't we ask them to aspire not to almost undetectable non-prototypical bullshit but perhaps to prototypical bullshitthe kind I tried my hand at in very beginning of this talk, though perhaps not so clumsy and obvious.

Here's what I mean. Academic bullshit, Schaeffer and I have claimed, is not "characterized by outrageousness but rather by earnestness (indeed, by earnest tedium)." We academics often write essays and books that live up to very particular standards of academic diligence and truthfulness and are, therefore, both earnest and tedious. And we feel little reticence about teaching our students to write the same way - to have them pretend to be like us. Sometime back, in his essay "Inventing the University," David Bartholomae put it this way, to quote him a bit elliptically: A student has to write "as though he were a member of the academy . . . mimicking its language. . . . He must learn to speak our language. Or he must dare to speak it or to carry off the bluff." Carry off the bluff? What can that mean except to bullshit us by pretending to be like us? Exacting. And maybe a little dull.

Yet it seems to me that there is a disconnect in this that needs to be reconnected. True, academic writing serves an important purpose. But knowing how to write academically isn't the same thing as knowing how to write. When I teach so-called "advanced composition," I am less concerned with 
academic standards than with good writing in the form it takes outside of the walls of the university. In other words, I'm concerned not with writing that people need to read but with writing people want to read.

A lot of us, a lot of the time, like to read prototypical bullshit. By which I mean: writing that significantly misrepresents the self, that engages in rhetorical gamesmanship, and that sounds-and perhaps is-incredible. I'm not referring to the mother of all bullshit: fiction. I'm referring to workaday, published non-fiction. One function of bullshit in much good writing is to gain and hold a reader's attention. It can also lead readers to valuable ideas, even if the method is not entirely on the up-and-up.

Along these lines, I have selected readings for my advanced composition students that involve a certain amount of writerly bullshit. Not "Letter from the Birmingham Jail." Not "Politics and the English Language." Certainly not Emerson or Susan Sontag or E.B. White or Joan Didion or-you complete the list. Why not these, the greatest of essayists, you may wonder? Because: The greatest fault of student writing is its dullness. The great writers may well be interesting, but they are also subtle and serious. And they have their ways. Students, I want to suggest, need an overdrawn example, where the rhetorical strategies are more obvious and, frankly, more appealing.

So I've been looking for readings that satisfy two criteria. First, I think students will want to read them. Second, I want to read them-and I mean read them when I'm not being good.

Let me mention an example and do some bullshit analysis on it.

There is a U.S. news publication called The Week. It features a weekly essay in the back, which is usually carved out from 
an article or a book published elsewhere. I have assigned a few of these essays because, it seemed to me, they are meant to be a treat at the end of the magazine. They not only attract readers; they attract happy readers. And the essays are pretty smart, too. This one appealed to me, and it appealed to my students also: "Why Books Are Overrated" by Mikita Brottman. The essay is stitched together, using excerpts from her book The Solitary Vice.

Listen to that essay's title (crafted by The Week, not by Brottman, no doubt, but not unfairly). "Why Books Are Overrated." What bullshit. And what a wonderful quality of bullshit the title promises. It doesn't sound quite like a lie. A lie is meant to deceive, undetected. But bullshit can walk the line between concealment and display-as if the speech act were: "I dare you not to believe this." Before reading the first word of "Why Books Are Overrated," you probably have the feeling that Brottman doesn't really and truly believe what she's about to tell you.

In fact, I think I can demonstrate that she doesn't believe it at all. She is a psychoanalyst who teaches on the college level. In her spare time, she reviews books. Here's a short selection from one of her blog posts:

- Since I occasionally review books for various websites, I was recently given the opportunity to list my top ten books of 2007. After a little thought, however, I had to decline. Not because I didn't read any books in 2007 - on the contrary, I read far too many, as usual.

- If, like me, you're a regular book buyer, looking back at your Amazon.com order history is like looking at a record of your year (try it and see). There are all the year's urges and impulses, laid out before you in black and white. 
- There are certain titles...that remind me vividly of the summer - books that I carried around in my backpack along with sun tan oil and mosquito spray, like A Bark in the Park - 50 Best Places to Hike with your Dog in Baltimore. I read Daniel Menaker's The Treatment, floating in an inner tube in a cool pond; The Sisters - The Saga of the Mitford Family by Mary S. Lowell immediately brings to mind the sound of crickets and a swimming pool filter.

I cannot read those passages and still believe Brottman when she warns us about the harm that books can do. She loves books. She loves nothing more than books. However, I do believe her when she writes, less extravagantly, in The Week that "books can take you to wonderful places, but they can leave you stranded there, isolated from other human beings, even from your own experience." That is her point, after allthat books, to some degree, can lure people away from social interaction and honest self-examination.

But I forgive her for bullshitting me. The fact is, her bullshitting is a good rhetorical strategy. To begin with, her statement is pretty startling. Have you ever given the advice, "Begin with a startling statement"? I have. But did you add, "Lie if you have to"? If Brottman's title is a lie, it is a useful one because it contradicts everything everybody who matters in the literate world believes about books. In the opening of her essay in The Week, she recites the full litany of proreading catch phrases: "Get caught reading." "Read and grow." "Reading is fundamental." To all of that Brottman says, in a word, Bullshit. Reading is dangerously intoxicating. It is isolating. As critics of reading from centuries past warned us, books are full of dangerous ideas. Brottman claims to be harmed herself by overly idealized depictions of love in the Victorian novels she once devoured-fancy notions that made all of her youthful experience with love doubly painful and 
unsatisfying and drove her to withdraw from the world almost entirely.

But is that really so? If not for books, would Brottman's youth have been spent drinking in the world, up-close and personal? Would she have adjusted her expectations to the real world of love and sex? Or is she bullshitting us, just a little, when she writes,

Reading Jane Eyre convinced me that, if it could happen to Jane, it could happen to me. [But] nobody ever asked for my hand in marriage. Nobody even called me on the phone. The more real life disappointed me, the more I buried myself in books; and the longer I spent reading, the more remote grew the possibility of actual escape.

You may be thinking, "But wait, I was a bookworm who used escaped into literary fantasies! That was my life!" It's one of the good things about good bullshit that it sounds sort of true. But let's be boringly honest here. A lot of people have had a tough adolescence, and books may be one form of adolescent escape, but that's not a good reason to warn people off of them.

My co-author John Schaeffer was once asked on a radio program, "Who is the most important person of the past thousand years?" He said, "Gutenberg. Without him, nothing else could have happened." Isn't the plain, boring truth that books may have unintended side-effects, but that they are supremely important-and not over-rated at all? And isn't it also true that putting it that way would make for a duller essay than the one Brottman wrote?

Of course, not all bullshit succeeds-at least, not with my advanced composition students. I've twice assigned, for example, a chapter from Randall Robinson's Quitting America. Robinson is famous for advocating that reparations be paid to the descendants of slaves. In Quitting America, a memoir 
about moving to the Caribbean island St. Kitts, his views about race and about the United States are not understated. When I have assigned Robinson, I have braced myself for an uncomfortable conversation about race. But it hasn't materialized. Instead, my students have complained that he is a bullshitter. That he tries to pass off as true things that just make no sense to them.

To wit: Denouncing violence in America, he discusses a kid he once knew, Mordecai, who tortured animals-for example, killing a frog just for the fun of it: Writes Robinson, "If Mordecai had to "buy a license," "buy a hunting rifle," buy "more paraphernalia," "pile into . . . a car at three or four in the morning," and then "shiver in the woods . . . for hours" in order to kill the frog, he would have "foregone the pleasure" (9). That is to say, Who are the crazy ones? Psychopathic Mordecai? Or the members of the National Rifle Associationknown otherwise in the U.S. as the "gun lobby"? My students called him on this. Hunting may not be to everyone's taste, but hunters are not, generally speaking, psychopaths.

Of course, that's just the kind of claim most of us teach our students not to make. A claim needs credible support, we say. True, the academic community-and writing studies in particular-has mostly moved beyond an unproblematized advocacy of thesis and support. But the way we have moved on has been to recognize that truth is complicated, that where you stand depends on where you sit. We have talked a lot about discourses and geographies. We don't often advocate truth with a capital T. But we're not averse to real with a capital $\mathrm{R}$.

We may not have talked enough about what it takes to write something that people will be drawn to. That is largely because we have some duty to teach academic writing. Yet that's not all we teach. And when we teach other kinds of 
writing, I'm wondering if we would be more honest if we advocated a certain kind of lying: bullshit.

I don't mean benign, non-prototypical bullshit, either. I mean writing that might cause someone to say, "What bullshit!" Writing that adopts a pose. Writing that makes a claim that is stretched to the point of breaking. Writing in which evidence is selected, uh, selectively.

If I'm right about that, then there is a second figure we need to deal with-at least one. That is the metaphor of voiceand, in particular, the version that is associated with the core self or and speaking one's mind. I suspect that more "writerly" the writing, the less concerned we need to be about authentic selves and authentic voices. I suspect we need to be concerned with the writer's license to stray from the truth. To lie. Or, at least, to bullshit. 0

\section{Works Cited}

Bartholomae, David. "Inventing the University." Cross-Talk in Composition Theory: A Reader. Ed. Victor Villanueva, Jr. Urbana: NCTE, 1997. Print.

Brottman, Mikita. "Why Books Are Overrated." The Week. 16 May 2008. 44-45. Print.

---. "Book Buying: A Record of Your Year." The Huffington Post. 23 December 2007. Web. 16 November 2009.

Coleman, Linda and Paul Kay. "Prototype Semantics: The English Word Lie." Language 57 (1981): 26-44. Print.

Frankfurt, Harry G. On Bullshit. Princeton, NJ: Princeton University Press, 2005. Print.

Robinson, Randall. Quitting America: The Departure of a Black Man from His Native Land. New York: Dutton, 2004. Print. 
Rosch, E. "On the Internal Structure of Perceptual and Semantic Categories." Cognitive Development and the Acquisition of Language, Ed. T. E. Moore. 111-44. New York: Academic Press, 1973. Print.

Philip Eubanks is Professor of English and Chair of the Department of English at Northern Illinois University. He holds a Ph.D. in English (Center for Writing Studies) from the University of Illinois at Urbana-Champaign and specializes in writing studies and figurative language and thought. 